\title{
Research on tourists' satisfaction with the gastro offer of Novi Sad
}

\section{Истраживање задовољства туриста гастро понудом Новог Сада}

\author{
Živana Krejić \\ Union University, Faculty of Business Studies and Law, Belgrade, Republic of Serbia, \\ zivana.krejic@fpsp.edu.rs
}

\section{Snežana Milićević}

University of Kragujevac, Faculty of Hotel Management and Tourism Vrnjačka Banja, Vrnjačka Banja, Republic of Serbia, snezana.milicevic@kg.ac.rs

Abstract: Vojvodina has long been known as an area of high-quality and varied food. In this regard, gastro tourism in its capital is one of the most attractive tourism products. That is the reason why our research was conducted in Novi Sad, aimed to examine the satisfaction of domestic and foreign tourists with the gastro offer of this city. The results of the research show that the gastro offer of Novi Sad is an important motive in attracting both domestic and foreign tourists, but that foreign tourists are still more satisfied with it. Further, there are differences in attitudes between male and female tourists, because male tourists show a higher degree of satisfaction with the gastro offer compared to female tourists, while other socio-demographic characteristics (education and age) are not related to the degree of their satisfaction. The results of the research can be useful in the development of future strategies for the development of tourism in Novi Sad and Vojvodina. They can also serve as a model for analysing tourists' satisfaction with other forms of tourism offer.

Keywords: satisfaction, tourists, gastro offer, Novi Sad, Vojvodina.

JEL classification: L83, Z32.

Сажетак: Војводина је од давнина позната као подручје квалитетне и разноврсне хране. С тим у вези, гастро туризам у њеном главном граду представља један од атрактивнијих туристичких производа. То је разлог због чега је у Новом Саду спроведено истраживање које је имало циљ да испита задовољство домаћих и страних туриста гастро понудом овог града. Резултати истраживања показују да је гастро понуда Новог Сада важан мотив у привлачењу и домаћих и страних туриста, али да су њоме ипак задовољнији страни туристи. Такође, постоје разлике у ставовима између мушкараца и жена, јер мушкарци исказују виши степен задовољства гастро понудом у односу на жене, док остале социодемографске карактеристике (образовање и године старости) нису повезане са степеном њиховог задовољства. Резултати истраживања могу бити од користи при изради будућих стратегија развоја туризма Новог Сада и Војводине. Такође, могу послужити и као модел за анализу задовољства туриста другим облицима туристичке понуде.

Кључне речи: гастро понуда, задовољство, туристи, Нови Сад, Војводина.

JEЛ класификација: L83, Z32.

* Corresponding author 


\section{Introduction}

At the global level, tourism is an industry that is growing fast and has a significant economic contribution, because it generates exports of \$ 1.7 trillion (Milićević et al., 2020). Constant changes in the tourist market, primarily on the side of tourist demand, have resulted in the emergence of specific forms of tourism, which includes gastro tourism (Skryl et al., 2018). One of the thematic types of tourism, with growing interest in recent years, is food tourism (Vuković \& Mosurović-Ružičić, 2020). The basis of a specific tourism product is the uniqueness, authenticity and local factors of the destination (Milićević \& Štetić, 2017). Gastro tourism primarily attracts tourists who study food and beverages and issues related to local gastronomy from various aspects: cultural, historical, religious, ethnological, anthropological, etc. (Bunja \& Kaplan, 2020; Obonyo et al., 2012). According to World Tourism Organization, gastronomy is a strategic element in defining the destination brand and image (UNWTO, 2012). In many countries, gastro tourism is one of the most dynamic segments of tourism that attracts a large number of tourists (Williams et al., 2014). Today, an increasing number of tourists highlight very positive impressions regarding gastro products as part of their tourism experience in the destination (Park et al., 2020). Considering that gastro tourism is one of the fastest growing tourism trends, the growth in the number of tourists whose motive for travel is related to gastronomy is expected in the future as well.

The gastro offer of Vojvodina is very different from the gastro offer of other regions in Serbia. This is primarily a consequence of Vojvodina being exposed to Central European influence throughout history, i.e., the influence of German, Hungarian, Austrian and Slovak cuisines. Of the total number of events organized in Vojvodina during the year, about $40 \%$ are gastro events. Therefore, in relation to the area it occupies in Serbia, it can be concluded that the region of Vojvodina invests the most in the organization of gastro events (Kilibarda et al., 2018). Banić-Grubišić \& Antonijević (2013) point out that gastro products represent a great chance for the future development of tourism and occupy a prominent place in creating the tourism product and creating the image of the destination.

The subject of this research is the analysis of the attitudes of domestic and foreign tourists about the gastro offer of Novi Sad, as one of the most attractive destinations in Serbia. The aim of the research is to determine the degree of tourists' satisfaction with the gastro offer of Novi Sad and whether there are differences in their attitudes, from the aspect of different socio-demographic characteristics. Socio-demographic characteristics of tourists, such as age, gender, education, working status and income, are often used in studies related to tourists and tourism destinations (Tomić et al., 2020; Milićević et al., 2020).

\section{Literature review}

Gastronomy is understood from the point of view of the historical development of the human diet, connecting nations and communities with creativity, participants' abilities, raw materials, traditions, methods and recipes, new technologies that contribute to and influence the human diet (Burešová et al., 2020). According to Stojković \& Milićević (2020) "ever 
since tourism became a global phenomenon, in recent decades there have been evident changes in the tourist demand" (p. 60). The decision of tourists to choose a particular destination is under influence of various factors (Đeri et al., 2017), such as tourist attractions of the destination, its offer of entertainment, culture, recreation, relaxation, but also gastro specialties (Ottenbacher \& Harrington, 2010). The gastro offer of a tourism destination can be one of the main motives for tourists to visit (Kim et al., 2010). Gastro tourism is the journey of tourists motivated by the elements of the gastro specialties of a particular area. Possibilities of valorising the gastronomy of a specific area are numerous and they range from classic restaurants to gastro tours. Typical activities of tourists are eating and drinking, learning how to prepare meals, buying products related to food, attending cooking courses and gastronomy festivals (Milićević \& Štetić, 2017). Boita, Anghelina and Costi (2014) state that gastro tourism is part of cultural tourism, which embraces traditional and culinary values in urban and rural settings with various specific activities. According to Martins (2016), gastronomy is an experience of participation in other cultures, connection with people, and places with a strong sense of self identity. Hall and Mitchell (2002) conclude that areas where technology and globalization have not changed the way of preparing and serving food and beverages, including consumption culture, have become very favourable for the development of gastro, that is culinary or gourmet tourism.

Gastro tourism plays an active role in the marketing of tourism destinations. At the same time, gastro tourism can be a huge opportunity for destinations that do not have natural beauties, such as coastal or mountainous destinations (Kurt \& Dłużewska, 2018). The development of gastro tourism is also positively reflected on the development of rural areas (Njegovan, et al., 2015), due to the increasing demand for fruits, vegetables and cereals. Thus, gastro tourism has positive economic and socio-cultural effects on the development of the local community, but also on regional development (Gálvez et al., 2017; Šimičević \& Štetić, 2011).

Research by numerous authors indicates that gastro tourists belong to the category of tourists who have a high level of education and income (Ardabili et al., 2011; Lee et al., 2015; Şimşek \& Selçuk, 2018), which allows them to visit new destinations, get to know the local tradition and taste local gastronomic specialties (Dan, 2013). Today, more and more people travel motivated by gastronomy, so that food and drink are no longer just a complementary element of a destination's offer, but become a primary element of the tourism offer (López-Guzmán \& Sánchez-Cañizares, 2012). Gastro tourism can be determined as a deliberate search for an attractive, authentic, unforgettable experience (Williams et al., 2014). Sormaz et al. (2016) also state that gastro tourism is one of the decisive factors in attracting tourists to a destination.

In recent years, the gastro offer of Serbia has become increasingly attractive for tourists (Čerović et al., 2015). Traditional food can have many positive effects on preserving local tradition, culture, old crafts, and the possibility to employ local residents (Krejić et al., 2016). Many domestic authors in their research deal with the potential for the 
development of gastro tourism in Vojvodina. Some of them emphasize authentic food as a great potential (Kalenjuk et al., 2017), while others point to the possibility of developing specific destinations in Vojvodina, where quality food is the main motive for the arrival of domestic and foreign tourists (Vujko et al., 2016). Within the analysis of the development of tourism in Novi Sad, gastro tourism stands out as one of the main motives for the arrival of foreign tourists and a very attractive tourism product (Tourism Development Program of Novi Sad, 2018).

\subsection{Methodological framework}

A survey of tourists who visited Novi Sad was conducted during January 2020, with the aim of examining the degree of satisfaction of domestic and foreign tourists with the gastro offer of Novi Sad, i.e., to determine whether their attitudes differ. Further, the aim of the research is to determine whether there are differences in the attitudes of tourists about the gastro offer of Novi Sad in relation to their socio-demographic characteristics (gender, education and age).

In order to collect the necessary data, the survey of tourists was conducted in Novi Sad hotels, so that tourists filled out printed questionnaires handed to them by receptionists when checking out of the hotel. 250 questionnaires were answered by 204 respondents, of which 102 were domestic and 102 foreign tourists. The questionnaire consisted of two parts. The first part referred to the socio-demographic characteristics of the respondents, while the second part consisted of five statements referring to the gastro offer of Novi Sad. Tourists expressed their views using a seven-point Likert scale, with a score of 1 indicating the lowest score (I completely disagree), while a score of 7 indicates the highest score (I completely agree).

Based on the subject and goal of the research, the following hypotheses are set in the paper:

$\mathrm{H}_{1}$ : There are statistically significant differences in the attitudes of domestic and foreign tourists regarding the gastro offer of Novi Sad;

$\mathrm{H}_{2}$ : There are statistically significant differences in the attitudes of tourists about the gastro offer of Novi Sad in relation to gender;

$\mathrm{H}_{3}$ : There are statistically significant differences in the attitudes of tourists about the gastro offer of Novi Sad in relation to their level of education;

$\mathrm{H}_{4}$ : There are statistically significant differences in the attitudes of tourists about the gastro offer of Novi Sad in relation to age.

The research process was conducted in the following stages: data collection, sorting, data grouping and statistical analysis using SPSS statistical program, version 17.0.0 and Microsoft Office Excel program for further processing. The data were first processed using descriptive methods and then inferential statistics. 


\section{Results and discussion}

As already mentioned, the survey included 204 respondents of which 102 (50\%) domestic tourists, and the same number of foreign tourists (102, i.e., 50\%). Of the total number of respondents, 105 were male $(51.5 \%)$ and 99 female $(48.5 \%)$. The average age of foreign tourists was 40.6 , while of domestic tourists 39.6 years. In terms of tourist education, the largest number of both domestic and foreign respondents have a university degree (Table $1)$.

Table 1: Socio-demographic characteristics of the respondents

\begin{tabular}{|l|l|c|c|}
\hline \multicolumn{2}{|l|}{} & Foreign tourists (n=102) & Domestic tourists (n=102) \\
\hline Age & Average value & 40.6 & 39.6 \\
\hline & Median & 38.5 & 39.0 \\
\hline & SD & 8.9 & 8.1 \\
\hline & Span & $24-65$ & $25-59$ \\
\hline male & $\mathrm{N}(\%)$ & $52(51.0 \%)$ & $53(52.0 \%)$ \\
\hline & $\mathrm{N}(\%)$ & $50(49.0 \%)$ & $49(48.0 \%)$ \\
\hline High school & & & $19(18.6 \%)$ \\
\hline College & $\mathrm{N}(\%)$ & $21(20.6 \%)$ & $28(27.5 \%)$ \\
\hline University Degree & $\mathrm{N}(\%)$ & $33(32.4 \%)$ & $47(46.1 \%)$ \\
\hline Master's Degree & $\mathrm{N}(\%)$ & $45(44.1 \%)$ & $8(7.8 \%)$ \\
\hline PhD & $\mathrm{N}(\%)$ & $3(2.9 \%)$ & $0(0.0 \%)$ \\
\hline
\end{tabular}

Source: the authors' research

According to the aforementioned, domestic and foreign tourists evaluated the gastro offer of Novi Sad using the seven-point Likert scale. Based on the data from Table 2, it can be concluded that tourists (both domestic and foreign) rated the gastro offer of Novi Sad with a high average score (6.03). The average rating of foreign tourists is higher (6.36) in relation to the ratings of domestic tourists (5.71). The results of the Mann-Whitney test showed that $\mathrm{p}<0.001$, indicating a significant statistical difference in response scores between domestic and foreign tourists. Based on the obtained results, it is concluded that there are statistically significant differences in the attitudes of domestic and foreign tourists regarding the gastro offer of Novi Sad, whereby hypothesis H1 is accepted.

Table 2: Satisfaction of domestic and foreign tourists with the gastro offer of Novi Sad

\begin{tabular}{|c|c|c|c|}
\hline Rates & All respondents & $\begin{array}{c}\text { Domestic tourists } \\
\mathrm{n}=102\end{array}$ & $\begin{array}{c}\text { Foreign tourists } \\
\mathrm{n}=102\end{array}$ \\
\hline Average value & 6.03 & 5.71 & 6.36 \\
\hline Median & 6 & 6 & 7 \\
\hline SD & 1.205 & 1.411 & 0.842 \\
\hline Span & $2-7$ & $2-7$ & $4-7$ \\
\hline Scale 1-7 & & & \\
$1 \mathrm{~N}(\%)$ & $0(0.0)$ & $0(0.0)$ & $0(0.0)$ \\
2 N (\%) & $4(2.0)$ & $4(3.9)$ & $0(0.0)$ \\
$3 \mathrm{~N}(\%)$ & $4(2.0)$ & $4(3.9)$ & $0(0.0)$ \\
\hline
\end{tabular}




\begin{tabular}{|l|c|c|c|}
\hline $4 \mathrm{~N}(\%)$ & $17(8.3)$ & $13(12)$ & $4(3.9)$ \\
$5 \mathrm{~N}(\%)$ & $29(14.2)$ & $17(16.7)$ & $12(11.8)$ \\
$6 \mathrm{~N}(\%)$ & $52(25.2)$ & $23(22.5)$ & $29(28.4)$ \\
$7 \mathrm{~N}(\%)$ & $98(48.0)$ & $41(40.2)$ & $57(55.9)$ \\
\hline Total N (\%) & $204(100)$ & $102(100)$ & $102(100)$ \\
\hline
\end{tabular}

Source: the authors' research

The second hypothesis examines whether there are statistically significant differences in the attitudes of tourists about the gastro offer of Novi Sad in relation to gender. Tourists were asked through a questionnaire to express their degree of agreement/disagreement with the following statements: $\left(\mathrm{a}_{1}\right)$ The gastro offer of Novi Sad is very diverse and high quality; $\left(a_{2}\right)$ The offer of restaurants in Novi Sad satisfies the needs of different types of tourists; (a) I am very satisfied with the professionalism of the staff in Novi Sad restaurants; (a4) The diverse gastro offer makes Novi Sad more competitive compared to similar city destinations I have visited; (as) The gastro offer of Novi Sad is an attractive tourist motive for me. The results of the research show that there are statistically significant differences in attitudes between male and female tourists regarding the above listed statements. This is especially pronounced for statements $a_{3}$, $a_{4}$ and $a_{5}$ (Table 3). Namely, male tourists point out a higher degree of satisfaction with the professionalism of the staff in Novi Sad restaurants in relation to female tourists and believe that Novi Sad is more competitive on the market compared to other city destinations. In addition, for male tourists, the gastro offer of Novi Sad is a more attractive tourist motive compared to female tourists. Based on all the above, it can be concluded that hypothesis $\mathrm{H}_{2}$ is accepted.

Table 3: Satisfaction of domestic and foreign tourists with the gastro offer of Novi Sad in relation to gender (1-male, 2-female)

\begin{tabular}{|l|l|r|c|}
\hline & gender & $\mathrm{N}$ & Mean Rank \\
\hline \multirow{4}{*}{$a_{1}$} & 1 & 102 & 94.73 \\
\cline { 2 - 4 } & 2 & 102 & 94.08 \\
\cline { 2 - 4 }$a_{2}$ & Total & 204 & \\
\hline \multirow{3}{*}{$a_{3}$} & 1 & 102 & 99.58 \\
\cline { 2 - 4 } & 2 & 102 & 95.44 \\
\cline { 2 - 4 } & Total & 204 & \\
\hline \multirow{3}{*}{$a_{4}$} & 1 & 102 & 107.55 \\
\cline { 2 - 4 } & 2 & 102 & 92.93 \\
\cline { 2 - 4 } & Total & 204 & \\
\hline \multirow{4}{*}{$a_{5}$} & 1 & 102 & 118.74 \\
\cline { 2 - 4 } & 2 & 102 & 105.07 \\
\cline { 2 - 4 } & Total & 204 & \\
\cline { 2 - 4 } & 1 & 120 & 118.51 \\
\cline { 2 - 4 } & 2 & 204 & 102.67 \\
\hline
\end{tabular}

Source: the authors' research

Hypothesis $\mathrm{H}_{3}$ examines whether there are statistically significant differences in the attitudes of tourists about the gastro offer of Novi Sad in relation to their level of education, while hypothesis $\mathrm{H}_{4}$ examines the differences in attitudes of tourists in relation to their age. 
Based on the data from Table 4, it can be seen that the relationship between the age of tourists $\left(\mathrm{y}_{1}\right)$ and the observed variables $\left(\mathrm{a}_{1}-\mathrm{a}_{5}\right)$ is weak. Therefore, it is concluded that there is a slight influence and that there is no correlation at a statistically significant level, because $p>0.05$. Also, in terms of examining the impact of the level of education of tourists on the degree of their satisfaction with the gastro offer of Novi Sad, it is negligible. The relationship between the level of education and the observed variables (a $\left.a_{1}-a_{5}\right)$ is weak and there is no statistically significant difference. Therefore, hypotheses $\mathrm{H}_{3}$ and $\mathrm{H}_{4}$ are rejected.

Table 4: Satisfaction of domestic and foreign tourists with the gastro offer of Novi Sad in relation to age $\left(y_{1}\right)$ and level of education $\left(y_{2}\right)$

\begin{tabular}{|c|c|c|c|c|c|}
\hline $\mathrm{r}_{0}(\mathrm{p})$ & $\mathrm{a}_{1}$ & $\mathrm{a}_{2}$ & $\mathrm{a}_{3}$ & $\mathrm{a}_{4}$ & $\mathrm{a} 5$ \\
\hline $\mathrm{y}_{1}$ & -.049 & -.019 & -.037 & -.031 & .022 \\
& $(.472)$ & $(.680)$ & $(.589)$ & $(.870)$ & $(.546)$ \\
\hline $\mathrm{y}_{2}$ & .011 & .128 & .038 & .033 & .105 \\
& $(.850)$ & $(.059)$ & $(.574)$ & $(.448)$ & $(.098)$ \\
\hline
\end{tabular}

Source: the authors' research

\section{Conclusion}

The search for attractive tourism destinations that will provide them with an authentic experience is the focus of today's contemporary tourists. Although Novi Sad is already a well-known gastro destination, creating an authentic gastro tourism offer would make this city an even more attractive gastro destination (Kalenjuk \& Tešanović, 2013), both for domestic and foreign tourists.

Based on the conducted research, it is concluded that there are statistically significant differences in the attitudes of domestic and foreign tourists when it comes to their satisfaction with the gastro offer of Novi Sad. Statistical differences are also evident in terms of certain socio-demographic characteristics of the respondents, more precisely in relation to the gender of the respondents. In relation to other socio-demographic characteristics examined in the paper (level of education and age of tourists), it is concluded that the connection with the variables is weak, i.e., that they do not affect the level of tourist satisfaction.

The results of the research have a scientific and practical contribution. The scientific contribution refers to the unification of the results of the satisfaction of domestic and foreign tourists regarding the gastro offer of Novi Sad. The practical contribution is reflected in the possibilities of using the research results in the process of developing future strategies for the development of tourism in Novi Sad and Vojvodina. Further, the results can serve in identifying the wishes and needs of contemporary tourists, and help the restaurateurs of Novi Sad in forming the gastro offer. The main limitations of the research relate to the period in which the survey of tourists was conducted. Future research on gastro tourism in Novi Sad should be conducted throughout the year, and expanded to other 
tourism destinations in Serbia, especially during large events, of which the gastro offer is an integral part.

\section{References}

Ardabili, F. S., Rasouli, E. H., Daryani, S. M., Molaie, M., \& Sharegi, B. (2011). The role of food and culinary condition in tourism industry. Middle-East Journal of Scientific

Research, 9 (6) 826-833.

Banić-Grubišić, A., \& Antonijević, D. (2013). The relationship between tradition, tourism and gastronomy: cuisine and culinary heritage in "salaš" (farm) tourism. Issues in Ethnology and Anthropology, 8(4), 1089-1108. Doi: https://doi.org/10.21301/eap.v8i4.10

Boita, M., Anghelina, A., \& Costi, B. (2014). Gastronomic tourism management revitalizer factor of the tourism offer. Annals - Economy Series, volume special, 398-401.

Bunja, D., \& Kaplan, M. (2020). Importance of tourism valorisation of Croatian gastrocultural heritage. Proceedings of $25^{\text {th }}$ Biennial International Congress, Tourism \& Hospitality Industry 2020, Trends and Challenges Opatija, Croatia, pp. 8-18.

Burešová, P., Mrkvová, K., \& Dudić, B. (2020). Changes in gastronomy. Hotel and Tourism Management, 8(1), 79-88. doi: https://doi.org/10.5937/menhottur2001079B

Čerović S., Barjaktarović D., \& Knežević M. (2015). Podrška razvoju turizma kao faktor konkurentnosti Srbije kao turističke destinacije, Proceedings of SITCON 2015 Singidunum International Tourism Conference Belgrade, Serbia, pp. 1-8. Doi: https://doi.org/10.15308/sitcon-2015-1-8

Gálvez, J. C. P., Granda, M. J., López-Guzmán, T., \& Coronel, J. R. (2017). Local gastronomy, culture and tourism sustainable cities: the behaviour of the American tourist. Sustainable Cities and Society, 32, 604-612. Doi: https://doi.org/10.1016/j.scs.2017.04.021

Dan, M. D. (2013). Gastronomic tourism - option for the development of local communities. Cactus Tourism Journal, 8(2), 42-43.

Đeri, L., Božić, S., \& Šašlić, S. (2017). Analysis of gender differences in destination decision-making. Megatrend revija - Megatrend Review, 14 (1), 47-62. Doi: https://doi.org/10.5937/MegRev1701047D

Hall, C. M., \& Mitchell, R. (2002). The changing nature of the relationship between cuisine and tourism in Australia and New Zealand: from fusion cuisine to food networks. In A. M. Hjalager \& G. Richards (Eds.), Tourism and Gastronomy, (pp. 188-206), London: Routledge.

Harrington, R. J., \& Ottenbacher, M. C. (2010). Culinary tourism- A case study of the gastronomic capital. Journal of Culinary Science \& Technology, 8(1), 14-32. Doi: https://doi.org/10.1080/15428052.2010.490765

Kalenjuk, B., \& Tešanović, D. (2013). Određivanje pravaca strategijskog razvoja gastronomskog turizma u Vojvodini, Ekonomika, 59 (4), 195-202. Doi:

https://doi.org/10.22004/ag.econ.290087 
Kalenjuk, B., Cvetković, B., \& Dević-Blanuša, J. (2017). Autentična hrana ruralnih područja Vojvodine i značaj za razvoj gastronomskog turizma. Turističko poslovanje, 20, 27-35. Doi: https://doi.org/10.5937/TurPos1720027K

Kilibarda, N., Pavlović, D., Borovčanin, D., \& Brdar, I. (2018). Gastronomske manifestacije kao deo turističke ponude nematerijalnog kulturnog nasleđa Srbije. Proceedings of SITCON 2018 - Singidunum International Tourism Conference Belgrade, Serbia, pp. 221-228. Doi: https://doi.org/10.15308/Sitcon-2018-221-228

Kim, Y. H., Goh, B. K., \& Yuan, J. (2010). A development of a multi-dimensional scale for measuring the motivation factors of food tourists as a food event: what motivates people to travel. Journal of Quality Assurance in Hospitality and Tourism, 11 (1), 56-71. Doi: https://doi.org/10.1080/15280080903520568

Krejić, Ž., Čerović, S., \& Milićević, S. (2016). Impact of socio-demographic characteristics on travel expenditures of Hungarian tourists in the village of Skorenovac. Economics of Agriculture, 63 (2), 601-615. Doi: https://doi.org/10.5937/ekoPolj1602601K

Kurt, G., \& Dłużewska, A. (2018). Gastro tourism potential and perspectives for Turkey - a theoretical approach. Czasopismo Geograficzne, 89 (1-2), 121-137.

Lee, K. H., Packer, J., \& Scott, N. (2015). Travel lifestyle preferences and destination activity choices of slow food members and non-members. Tourism Management, 46, 1-10. Doi: https://doi.org/10.1016/j.tourman.2014.05.008

López-Guzmán, T., \& Sánchez-Cañizares, S. (2012). Gastronomy, tourism and destination differentiation: a case study in Spain. Review of Economics \& Finance, 2, 63-72.

Martins, M. (2016). Gastronomic tourism and the creative economy. Journal of Tourism, Heritage \& Services Marketing, 2 (2), 33-37. Doi: https://doi.org/10.5281/zenodo.376346

Milićević, S., \& Štetić, S. (2017). Menadžment u turizmu, Vrnjačka Banja: Fakultet za hotelijerstvo i turizam u Vrnjačkoj Banji.

Milićević, S., Đorđević, N., \& Krejić, Ž. (2020). Research on tourists' attitudes on the potential of Mt Goč for the development of eco-tourism. Economics of Agriculture, 67(1): 223-238. Doi: https://doi.org/10.5937/ekoPolj2001223M

Milićević, S., Podovac, M., \& Đorđević, N. (2020). Local residents' attitudes towards tourism events: a case study of the Carnival of Vrnjci, Serbia. Ekonomika, 66(2), 75-91. doi: https://doi.org/10.5937/ekonomika2002075M

Njegovan, Z., Demirović, D., \& Radović, G. (2015). Upravljanje održivim razvojem ruralnog turizma u Vojvodini. Škola Biznisa, 1, 68-79. Doi:

https://doi.org/10.5937/skolbiz1-7899

Obonyo, G. O., Ayieko, M. A., \& Kambona, O. O. (2012). An importance-performance analysis of food service attributes in gastro-tourism development in Western Tourist 
Circuit, Kenya. Tourism and Hospitality Research, 12 (4), 188-200. Doi: https://doi.org/10.1177/1467358413491132

Park, E., Kim, S., \& Xu, M. (2020). Hunger for learning or tasting? An exploratory study of food tourist motivations visiting food museum restaurants. Tourism Recreation Research, Doi: https://doi.org/10.1080/02508281.2020.1841374

Tourism Development Program of Novi Sad, 2018-2022. Retrieved November 10, 2020, from http://www.novisadinvest.rs/sites/default/files/attachment/3.2_program_razvoja_turizma_g ns 2018-2022.pdf.

Şimşek, A., \& Selçuk, G. N. (2018). Determination of gastro-tourists' typology: an exploration in Gaziantep. International Journal of Turkic World Tourism Studies, 3 (1), 2843.

Skryl, T., Gregorić, M., \& Dugi, V. (2018). Culinary trends in the Republic of Croatia as part of gastro tourism development. European Research Studies Journal, 21 (3), 465-475. Doi: https://doi.org/10.35808/ersj/1075

Sormaz, U., Akmese, H., Gunes, E., \& Aras, S. (2016). Gastronomy in tourism. Procedia Economics and Finance, 39, 725-730. Doi: https://doi.org/10.1016/S2212-5671(16)30286$\underline{6}$

Stojković, J., \& Milićević, S. (2020). SWOT analysis of wine tourism development opportunities in the Trstenik vineyard district. Hotel and Tourism Management, 8 (1), 5967. Doi: https://doi.org/10.5937/menhottur2001059S

Tomić, S., Leković, K., Eskerod, P., \& Zedlacher, E. (2020). Profile of rural tourism consumers in Serbia and Austria. Anali Ekonomskog fakulteta u Subotici-The Annals of the Faculty of Economics in Subotica, 56 (44), 81-95. Doi:

https://doi.org/10.5937/AnEkSub2044081T

Šimičević, D., \& Štetić, S. (2011). Importance of local sales of agricultural production through the creation of specialized gastro tourism products. Economics of Agriculture, 58 (1), 255-264.

UNWTO (2012). Global report on food tourism. Retrieved December 10, 2020, from https://www.e-unwto.org/doi/epdf/10.18111/9789284414819

Vujko, A., Vujnić, J., Gajić, T., \& Petrović, M. (2016). Kvalitet usluga u turističkim preduzećima kao model upravljanja turističkom destinacijom. Škola Biznisa, 1, 22-31. Doi: https://doi.org/10.5937/skolbiz1-11596

Vuković, P., \& Mosurović-Ružičić, M. (2020). Potentials for development food tourism in AP Vojvodina in the Republic of Serbia. Ekonomika, 66(1), 77-92. Doi: https://doi.org/10.5937/ekonomika2001077V

Williams, H. A., Williams Jr, R. L., \& Omar, M. (2014). Gastro- tourism as destination branding in emerging markets. International Journal of Leisure and Tourism Marketing, 4 (1), 1-18. Doi: https://doi.org/10.1504/IJLTM.2014.059257 